\title{
Cancer Risk Assessment of Trihalomethanes Exposure in Tap and Swimming Pool Water in Kuantan Hotel
}

\author{
${ }^{1}$ M.E.S Marekan, ${ }^{2}$ A.A.Suhaimi, ${ }^{3}$ N.M.Hussin and ${ }^{4}$ R.A.Romzay \\ ${ }^{1,2,3,4}$ Faculty of Engineering Technology, University Malaysia Pahang, 26300, Kuantan, Pahang, Malaysia
}

\begin{abstract}
Chlorination is a common disinfection method for tap and swimming pool water as it is the most effective and low-cost method compared with others. The purpose of the study was to assess cancer risk of THMs exposure in tap and swimming pool water in Kuantan hotels. Temperature and $\mathrm{pH}$ were analyzed as an in-situ measurement while the rest of the parameters were analyzed in the laboratory. The concentration of four forms of THMs in tap and swimming pool water analyzed from Hotel $X$ are $1.23 u g / L$ and $1.35 u g / L$ for $\mathrm{CHCl}_{3}$ respectively and none for the $\mathrm{CHCl}_{2} \mathrm{Br}, \mathrm{CHClBr}_{2}$ and $\mathrm{CHBr}_{3}$. The concentration of four forms of THMs in tap and swimming pool water at Hotel $\mathrm{Y}$ are $1.25 \mathrm{ug} / \mathrm{L}$ and $1.18 \mathrm{ug} / \mathrm{L}$ respectively for $\mathrm{CHCl}_{3}$ and none for the $\mathrm{CHCl}_{2} \mathrm{Br}_{1} \mathrm{CHClBr}_{2}$ and $\mathrm{CHBr}_{3}$. The cancer risk from exposure to THMs at $\mathrm{Hotel} \mathrm{X}$ are $1.6 \times 10^{-}$ ${ }^{5}$ for tap water, $1.9 \times 10^{-5}$ for swimming pool water and $2.0 \times 10^{-4}$ for both tap and swimming pool water while cancer risk from exposure to THMs at Hotel Y are $1.7 \times 10^{-5}$ for tap water, $1.6 \times 10^{-5}$ for swimming pool water and $1.19 \times 10^{-4}$ for both tap and swimming pool water.Thus, it shows that, it is in range of acceptable risk.
\end{abstract}

Index term- Cancer Risk Assessment, Trihalomethanes Exposure, Tap and Swimming Pool Water

\section{INTRODUCTION}

Human body compose of up to more than $60 \%$ water. In spite of that, water composition in blood, brain and muscles, and bones are $92 \%, 75 \%$ and $22 \%$ respectively. Therefore, water plays an important role on human body to function well. Water is needed to assist in nourishing human body by allowing nutrients to flow as well as to hydrate cells to maintain optimum body temperature. Furthermore, a human can survive a month or more without eating food but they only can survive a week without drinking water.

On the other hand, water also important to the economy growth and social well being. We used water for bathing, washing, cooking, farming. industrial activities and many more. Considering the current world population, the demand for water consumption is exponentially significant. As stated by [1], about $80 \%$ of the world's population are exposed to the high level of water security threat. Besides that, the existing freshwater resources also increasingly becoming unavailable and polluted due to the human activities. Due to the pollution happened in the freshwater resources, there are many effective solution and robust method to treat water to fulfill the demand of water consumption. However, some of water treatment involved disinfenction step that utilized ozonization and chlorination method that implement to remove the entire biological contaminants and control the human pathogens can affect the human health chronically.

\section{LITERATURE REVIEW}

\subsection{Disinfection Method-Chlorination}

In order to supply water for human consumption, several methods applied in water treatment are typically involved coagulation-flocculation, sedimentation, filtration, and disinfection method before the water can be distributed to the users. Disinfection method is used to deactivate and remove the pathogenic microorganisms and also to prevent the growth of those microorganism in the plumbing system after distribution that can cause water to be recontaminated. One of the most effective agent in disinfection process are chlorine. Chlorine are commonly used due to its effectiveness and economical value [2]. Besides that, chlorination process are important to protect human health from pathogens such as Salmonella typhi bacteria, Vibrio cholerae bacteria, Shigella dysenteriae bacteria and Giardia lamblia protozoa [3].

\subsection{Effect of Chlorination - Trihalomethanes (THMs)}

Most of developing countries used chlorine to disinfect water supply to eliminate or control the waterborne disease. About $90 \%$ of water supply system in Canada use chlorine for disinfection 
purposes [4]. The reaction between natural organic matter in the source water and chlorine in the water during disinfection are generate disinfection by product (DBPs) like THMs and HAAs [5]. As stated by [6], this formation is rely on the several factors including concentration and nature of natural organic matter, raw water quality, disinfection contact time, temperature and $\mathrm{pH}$ value of water as well as the chlorine dose. According to [2], THMs formation consists of several carcinogenic compound that potentially cause cancer to the human health such as chloroform $\left(\mathrm{CHCl}_{3}\right)$, dichlorobromomethane $\left(\mathrm{CHCl}_{2} \mathrm{Br}\right)$, chlorodibromomethane $\left(\mathrm{CHClBr}_{2}\right)$ and bromoform $\left(\mathrm{CHBr}_{3}\right)$. In spite of cancer, these kind of carcinogenis compound also can cause various health effects to the human health such as abortion or teratogenic babies and children with asthma from inhaling THMs vapour [7-9].

\subsection{Routes of Exposure to THMs}

THMs exposure might affects human health from several exposure route such as ingestion during, swimming or bathing, contact with skin as dermal adsorption as well as inhalation of the compound. In Hong Kong, the cancer risk and hazard index of THMs from tap water that exposed through ingestion route is higher than dermal and inhalation [10]. Besides that, [11] stated the $\mathrm{CHCl}_{3}$ in water possesed highest risk from inhalation exposure during shower in Taiwan and it showed the dermal adsorption is not significant compared to oral and inhalation route. Another study from Thailand identified that THMs in the tap water and swimming pool water in Nakorn Pathom showed higher THMs concentration level in swimming pool water than tap water and the cancer risk from skin exposure during swimming was $94.18 \%$ of the total risk [12]. The study that conducted by [13] found the swimming pool water contained higher THMs compared to the tap water. The swimmers exposed up to 141 times higher THMs than bathing by using the tap water for 10 minutes. According to [9] the indoor swimming pool water had a higher concentration of THMs compared to the oudoor swimming pool water.

\section{METHODOLOGY}

\subsection{Study Area}

This study were conducted at two selected hotel in Kuantan. The hotel is chosen because of high numbers of tourist and offers a wide range of accommodation, meetings and convention selections. The hotel towers, which is part of the largest development on the East Coast of Malaysia, is set to stand at the highest building featuring a distinct modern façade that will majestically alter Kuantan's skyline. With this reasons, there are exposed to the usage of the swimming pool and tap water.

\subsection{Sample Collection}

Tap water and swimming pool water were collected from theselected hotels by following [14] during July 2014 - September 2014.

\subsubsection{Tap Water}

Tap water was collected from the selected room in the hotel. Before sampling, tap water is discarded for $5 \mathrm{~min}$ to make sure samples are collected from the main pipe, not the remaining in the tap water.

\subsubsection{Swimming Pool Water}

Swimming pool water was collected at the centre of the pool, the shallow side and the deep side. Swimming pool water collected at the centre of each side at the level of $30 \mathrm{~cm}$, below the water surface as the average level of human body exposure.

\subsection{Cancer Risk Calculation}

The cancer risk of a certain compound and one route is calculated by using equation 1 and equation 2 . Gastro-intestinal exposure while bathing and swimming: 
Chronic Dairy Intake, $C D I=\frac{C W \times I R \times E F \times E T \times E D}{B W \times A T}---(1)$

CW: chemical concentration in water $(\mathrm{d} / \mathrm{a}$, events/a)

IR: intake rate $(\mathrm{L} / \mathrm{d})$ or inhalation rate $\left(\mathrm{m}^{3} / \mathrm{h}\right)$

EF: exposure frequency (d/a, event/year)

ET: exposure time ( $\mathrm{h} / \mathrm{d}, \mathrm{h} / \mathrm{event})$

ED: exposure duration (year)

BW: body weight $(\mathrm{kg})$

AT: average time (d)

Skin exposure for total concentration:

Absorbed Dose, $A D=\frac{C W \times S A \times P C \times E C \times E F \times E D \times C F}{B W \times A T}---(2)$

CW: chemical concentration in water (d/a, events/a)

SA: skin surface area available for contact $\left(\mathrm{cm}^{2}\right)$

PC: chemical-specific dermal permeability contant $(\mathrm{cm} / \mathrm{h})$

EF: exposure frequency (d/a, event/year)

ED: exposure duration (year)

CF: volumetric conversion factor for water $\left(1 \mathrm{~L} / 1000 \mathrm{~cm}^{3}\right)$

BW: body weight $(\mathrm{kg})$

AT: average time (d)

\subsection{Data Analysis}

\subsubsection{Analysed Parameters}

The analysed parameters were $\mathrm{pH}$, temperature, THMs (in terms of $\mathrm{CHCl}_{3}, \mathrm{CHCl}_{2} \mathrm{Br}, \mathrm{CHClBr}_{2}$ and $\mathrm{CHBr}_{3}$ ).

Concentrations of the four forms of THMs were analysed by Gas Chromatography/Flame Ionization Detector, carrier gas with a flow rate of $25 \mathrm{ml} / \mathrm{min}$, GC heated time $999 \mathrm{~min}$ and operate temperature at $200^{\circ} \mathrm{C}$. Recoveries of all four THMs determined in spiked samples at the concentrations 1,5 , and $10 \mathrm{ppm}$ were in range of $99.1 \%-99.4 \%$. Water $\mathrm{pH}$ and temperature were analysed by Sartorius Model Professional Meter PP-50.

\subsection{Quality Assurance And Control}

The instrument used were calibrated to assure the accuracy of the data collected.

\section{RESULT AND DISCUSSION}

\section{$4.1 \mathrm{pH}$ Value $(\mathrm{pH})$}

The measurement procedure for $\mathrm{pH}$ is based on Electrometric method for $\mathrm{pH}$ value analysis 4500 $\mathrm{H}+\mathrm{B}$ [14]. The $\mathrm{pH}$ of a solution is the concentration of hydrogen ions, expressed as a negative logarithm. It reflects the acidity or alkalinity of a solution, in this case tap and swimming pool water. Table 1 shows the average $\mathrm{pH}$ value at each hotel. The average $\mathrm{pH}$ value was recorded at Hotel $\mathrm{X}$ in tap and swimming pool water were 7.6 and 7.1 respectively. The average $\mathrm{pH}$ value was recorded at Hotel Y in tap and swmming pool water were 6.9 and 7.0 respectively. Comparison with $\mathrm{pH}$ standard by [15] showed that all the sampling are in class 1 with $\mathrm{pH}$ range of $6.5-8.5$. The $\mathrm{pH}$ value obtained were in the reasonable $\mathrm{pH}$ value.The rate of THMs production increases with $\mathrm{pH}$. 
Table 1 pH value at Hotel $\mathrm{X}$ and Hotel $\mathrm{Y}$

\begin{tabular}{|c|c|c|c|}
\hline \multirow{2}{*}{ Hotel } & \multirow{2}{*}{ Location } & Range & pH Value \\
\cline { 3 - 4 } & Tap & $7.0-7.1$ & 7.1 \\
\hline \multirow{2}{*}{$\mathrm{X}$} & Swimming Pool & $7.5-7.6$ & 7.6 \\
\cline { 2 - 4 } & $\mathrm{Y}$ & $6.8-6.9$ & 6.9 \\
\cline { 2 - 4 } & Swap & $7.0-7.0$ & 7.0 \\
\hline
\end{tabular}

\subsection{Temperature}

Table 2 shows that, recorded temperature in tap and swimming pool water in Hotel $\mathrm{X}$ were $27^{\circ} \mathrm{C}$ and $25^{\circ} \mathrm{C}$ respectively. Meanwhile the temperature recorded at Hotel $\mathrm{Y}$ in tap and swimming pool water were $21^{\circ} \mathrm{C}$ and $24^{\circ} \mathrm{C}$ respectively. Comparison with temperature standard by [15] shown all the sampling are in green zone with the range $20^{\circ} \mathrm{C}-35^{\circ} \mathrm{C}$. This shown that the recorded temperature is at safe temperature range. A An increase in temperature increases the rate also was reported by [17].THMs formation and increasing $\mathrm{pH}$ results in high THMs formation.

Table 2 Temperature at Hotel $\mathrm{X}$ and Hotel $\mathrm{Y}$

\begin{tabular}{|c|c|c|c|}
\hline \multirow{2}{*}{ Hotel } & \multirow{2}{*}{ Location } & \multicolumn{2}{|c|}{ Temperature } \\
\cline { 3 - 4 } & & Range & Average \\
\hline \multirow{2}{*}{$\mathrm{X}$} & Tap & $26^{\circ} \mathrm{C}-28^{\circ} \mathrm{C}$ & $27^{\circ} \mathrm{C}$ \\
\cline { 2 - 4 } & Swimming Pool & $24^{\circ} \mathrm{C}-25^{\circ} \mathrm{C}$ & $25^{\circ} \mathrm{C}$ \\
\hline \multirow{2}{*}{$\mathrm{Y}$} & Tap & $20^{\circ} \mathrm{C}-21^{\circ} \mathrm{C}$ & $21^{\circ} \mathrm{C}$ \\
\cline { 2 - 4 } & Swimming Pool & $24^{\circ} \mathrm{C}-24^{\circ} \mathrm{C}$ & $24^{\circ} \mathrm{C}$ \\
\hline
\end{tabular}

4.3 Concentration of THMs in Swimming Pool

A total of 12 samples of swimming pool water were collected from Hotel X and Hotel Y. One compound (THMs) were detected in majority of the samples. Only chloroform could be quantified in all these sample. Dichlobromomethanes, dibromochhloromethanes and bromoform not detected for all samples under reviewed. Table 3 show the concentration of THMs in swimming pool in Hotel $\mathrm{X}$ and Y. The average concentrations of $\mathrm{CHCl}_{3}$ at Hotel $\mathrm{X}$ is $1.35 \mu \mathrm{g} / \mathrm{L}$. The highest and lowest $\mathrm{CHCl}_{3}$ recorded at Hotel X were $1.40 \mu \mathrm{g} / \mathrm{L}$ and $1.29 \mu \mathrm{g} / \mathrm{L}$ respectively. The standard deviation for $\mathrm{CHCl}_{3}$ at Hotel $\mathrm{X}$ is 2.66 . The average concentrations of $\mathrm{CHCl}_{3}$ at Hotel $\mathrm{Y}$ is $1.18 \mu \mathrm{g} / \mathrm{L}$. The highest ald lowest $\mathrm{CHCL}_{3}$ recorded at Hotel $\mathrm{Y}$ were $1.24 \mu \mathrm{g} / \mathrm{L}$ and $1.12 \mu \mathrm{g} / \mathrm{L}$ respectively. The standard deviation for chloroform at Hotel $\mathrm{Y}$ is 2.13 .

Table 3 Concentration of THMs in swimming pool in Hotel $X$ and $Y$

\begin{tabular}{|c|c|c|c|c|c|c|}
\hline \multirow{2}{*}{ Parameter } & \multicolumn{7}{|c|}{ Swimming Pool } \\
\cline { 2 - 7 } & \multicolumn{3}{|c|}{ Hotel X } & \multicolumn{3}{c|}{ Hotel Y } \\
\cline { 2 - 7 } & Range & Average & SD & Range & Average & SD \\
\hline $\mathrm{CHCl}_{3}(\mu \mathrm{g} / \mathrm{L})$ & $1.29-1.40$ & 1.35 & 2.66 & $1.12-1.24$ & 1.18 & 2.13 \\
\hline $\mathrm{CHCl}_{2} \mathrm{Br}(\mu \mathrm{g} / \mathrm{L})$ & $\mathrm{ND}$ & ND & ND & ND & ND & ND \\
\hline $\left.\mathrm{CHClBr}^{2} \mu \mathrm{g} / \mathrm{L}\right)$ & $\mathrm{ND}$ & ND & ND & ND & ND & ND \\
\hline $\mathrm{CHBr}_{3}(\mu \mathrm{g} / \mathrm{L})$ & $\mathrm{ND}$ & ND & ND & ND & ND & ND \\
\hline Total THMs $(\mu \mathrm{g} / \mathrm{L})$ & $1.29-1.40$ & 1.35 & 2.66 & $1.12-1.24$ & 1.18 & 2.13 \\
\hline
\end{tabular}

$*$ ND: Not Detected. 
Twelve samples of tap water were collected at Hotel X and Hotel Y. One compound (THMs) were detected in majority of the samples. Only chloroform could be quantified in all these sample. Dichlobromomethanes, dibromochhloromethanes and bromoform not detected for all samples under reviewed. Table 4 show the concentration of THMs in tap water in Hotel X and Y. The average concentrations of $\mathrm{CHCl}_{3}$ at Hotel $\mathrm{X}$ is $1.23 \mu \mathrm{g} / \mathrm{L}$. The highest and lowest $\mathrm{CHCl}_{3}$ recorded at Hotel X were $1.32 \mu \mathrm{g} / \mathrm{l}$ and $1.10 \mu \mathrm{g} / \mathrm{l}$ respectively. The standard deviation for $\mathrm{CHCl}_{3}$ at Hotel $\mathrm{X}$ is 2.41 . The average concentrations of $\mathrm{CHCl}_{3}$ at Hotel $\mathrm{Y}$ is $1.25 \mu \mathrm{g} / \mathrm{L}$. The highest ald lowest $\mathrm{CHCL}_{3}$ recorded at Hotel Y were $1.37 \mu \mathrm{g} / \mathrm{l}$ and $1.14 \mu \mathrm{g} / \mathrm{l}$ respectively. The standard deviation for chloroform at Hotel $\mathrm{Y}$ is 2.33 .

Table 4 Concentration of THMs in tap water

\begin{tabular}{|c|c|c|c|c|c|c|}
\hline \multirow{2}{*}{ Parameter } & \multicolumn{6}{|c|}{ Tap Water } \\
\cline { 2 - 7 } & \multicolumn{3}{|c|}{ Hotel X } & \multicolumn{3}{c|}{ Hotel Y } \\
\cline { 2 - 7 } & Range & Average & SD & Range & Average & SD \\
\hline $\mathrm{CHCl}_{3}(\mu \mathrm{g} / \mathrm{L})$ & $1.10-1.32$ & 1.23 & 2.41 & $1.14-1.37$ & 1.25 & 2.33 \\
\hline $\mathrm{CHCl}_{2} \mathrm{Br}(\mu \mathrm{g} / \mathrm{L})$ & ND & ND & ND & ND & ND & ND \\
\hline $\left.\mathrm{CHClBr}^{*} \mu \mathrm{g} / \mathrm{L}\right)$ & ND & ND & ND & ND & ND & ND \\
\hline $\mathrm{CHBr}_{3}(\mu \mathrm{g} / \mathrm{L})$ & ND & ND & ND & ND & ND & ND \\
\hline Total $\mathrm{THMs}(\mu \mathrm{g} / \mathrm{L})$ & $1.10-1.32$ & 1.23 & 2.41 & $1.14-1.37$ & 1.25 & 2.33 \\
\hline
\end{tabular}

*ND: Not Detected.

\subsection{Comparison of Total THMs Concentration in Tap and Swimming Water with USEPA Standard Value}

The concentration of total THMs in tap water at Hotel X was $1.23 \mu \mathrm{g} / \mathrm{L}$ the range of $1.32 \mu \mathrm{g} / \mathrm{L}-$ $1.10 \mu \mathrm{g} / \mathrm{L}$ which is lower than USEPA Standard phase I $(80 \mu \mathrm{g} / \mathrm{L})$. The concentration of total THMs in tap water at Hotel $\mathrm{Y}$ was 1.25 the range of $1.37 \mu \mathrm{g} / \mathrm{L}-1.14 \mathrm{ug} / \mathrm{L}$ which is lower than USEPA Standard phase I $(80 \mu \mathrm{g} / \mathrm{L})$. It implies that tap water containing THMs at Hotel X and Y was safe for use. The concentration of total THMs in swimming pool water at Hotel X was $1.35 \mu \mathrm{g} / \mathrm{L}$ the range of $1.40 \mu \mathrm{g} / \mathrm{L}-1.29 \mu \mathrm{g} / \mathrm{L}$ which is lower than USEPA Standard phase I $(80 \mu \mathrm{g} / \mathrm{L})$. The concentration of total THMs in swimming pool water at Hotel Y was 1.18 the range of $1.24 \mu \mathrm{g} / \mathrm{L}-1.12 \mu \mathrm{g} / \mathrm{L}$ which is lower than USEPA Standard phase I $(80 \mu \mathrm{g} / \mathrm{L})$. It implies that tap water containing THMs at Hotel X and $\mathrm{Y}$ was safe for use.

From a reviewed literature, the concentration of total THMs in Thailand's tap water was in the range of $12.70-41.74 \mu \mathrm{g} / \mathrm{L}$ and for swimming pool water was in the range $26.15-65.09 \mu \mathrm{g} / \mathrm{L}$ [12]. It was found that the total THMs in Hotel $\mathrm{X}$ and $\mathrm{Y}$ are lower than mention countries. This might happened due to the difference in location and contact time to the water. In Thailand, the research take place at the most visited hotel while this research was conducted at the private place. Due to that, the frequency of the water chlorination is higher in Thailand compared to Hotel in Kuantan.

As comparison to the standard value, the total THMs at Hotel $\mathrm{X}$ and $\mathrm{Y}$ is lower than USEPA standard phase 1.

\subsection{Assessment of Cancer Risk From Exposure to THMs in Tap and Swimming Pool Water}

This research focused on the assessment of cancer risk from the exposure to THMs through two routes which are skin exposure while showering, skin exposure while swimming. In this research, the swimming pool is an outdoor type. Risk assessment was done by using chronic dairy intake and absorbed dose formula calculation. Table 5 shows the risk value at each hotel through tap and and swimming pool water. 
INTERNATIONAL JOURNAL OF ENGINEERING TECHNOLOGY AND SCIENCES (IJETS) Vol.6 (1) Dec 2016 DOI: http://dx.doi.org/10.15282/ijets.6.2016.1.2.1052

Table 5 Cancer risk value at Hotel $\mathrm{X}$ and Hotel $\mathrm{Y}$

\begin{tabular}{|c|c|c|c|}
\hline Parameter & Tap Water & Swimming Pool & Total Risk \\
\hline \multicolumn{4}{|c|}{ Assessment of cancer risk at Hotel X } \\
\hline $\mathrm{CHCl}_{3}$ & 1.23 & 1.35 & 2.58 \\
\hline $\mathrm{CHCl}_{2} \mathrm{Br}$ & ND & ND & 0.00 \\
\hline $\mathrm{CHClBr}_{2}$ & ND & ND & 0.00 \\
\hline $\mathrm{CHBr}_{3}$ & ND & ND & 0.00 \\
\hline Total risk & 1.23 & 1.35 & 2.58 \\
\hline \multicolumn{4}{|c|}{ Assessment of cancer risk at Hotel Y } \\
\hline $\mathrm{CHCl}_{3}$ & 1.25 & 1.18 & 2.43 \\
\hline $\mathrm{CHCl}_{2} \mathrm{Br}$ & ND & ND & 0.00 \\
\hline $\mathrm{CHClBr}_{2}$ & ND & ND & 0.00 \\
\hline $\mathrm{CHBr}_{3}$ & ND & ND & 0.00 \\
\hline Total risk & 1.25 & 1.18 & 2.43 \\
\hline
\end{tabular}

The results calculation for cancer risk from exposure of THMs at Hotel X are 1.6 x 10-5 for tap water, $1.9 \times 10-5$ for swimming pool and $2.0 \times 10-4$ for both tap and swimming pool water. The results of calculation for cancer risk from exposure to THMs at Hotel Y are $1.7 \mathrm{x}$ 10-5 for tap water, $1.6 \times 10-5$ for swimming pool and 1.19 x 10-4 for both tap and swimming pool water. According to [15], if cancer risk is in range of 10-4-10-6, it is an acceptable risk. Thus, this study has acceptable risk.

\section{CONCLUSION}

This research was performed by collecting water samples that later being analyzed for the concentration of THMs in the tap water and swimming pool water at Hotel X and Hotel Y. The concentration of four forms of THMs in tap water at Hotel X are $1.23 \mu \mathrm{g} / \mathrm{L}$ for $\mathrm{CHCl}_{3}$ and none for the $\mathrm{CHCl}_{2} \mathrm{Br}, \mathrm{CHClBr}_{2}$ and $\mathrm{CHBr}_{3}$. The concentration of four forms of THMs in swimming pool water at Hotel $\mathrm{X}$ are $1.35 \mu \mathrm{g} / \mathrm{L}$ for $\mathrm{CHCl}_{3}$ and none for the $\mathrm{CHCl}_{2} \mathrm{Br}, \mathrm{CHClBr}_{2}$ and $\mathrm{CHBr}_{3}$. The concentration of four forms of THMs in tap water at Hotel Y are $1.25 \mu \mathrm{g} / \mathrm{L}$ for $\mathrm{CHCl}_{3}$ and none for the $\mathrm{CHCl}_{2} \mathrm{Br}$, $\mathrm{CHClBr}_{2}$ and $\mathrm{CHBr}_{3}$. The concentration of four forms of THMs in swimming pool water at Hotel $\mathrm{Y}$ are $1.18 \mu \mathrm{g} / \mathrm{L}$ for $\mathrm{CHCl}_{3}$ and none for the $\mathrm{CHCl}_{2} \mathrm{Br}, \mathrm{CHClBr}_{2}$ and $\mathrm{CHBr}_{3}$. The cancer risk value from the exposure to THMs at Hotel X are $1.6 \times 10^{-5}$ for tap water, $1.9 \times 10^{-5}$ for swimming pool and $2.0 \mathrm{x}$ $10^{-4}$ for both tap and swimming pool water. The results calculation for cancer risk from exposure to THMs at Hotel Y are $1.7 \times 10^{-5}$ for tap water, $1.6 \times 10^{-5}$ for swimming pool and $1.19 \times 10^{-4}$ for both tap and swimming pool water respectively.

From the findings, it is not necessary to reduce the risk in the tap and swimming pool. The recommendations for risk management of the swimming pool include avoidance of mixing tap and swimming pool water with exceed clorine. According to [15], the uncertainty of risk assessment was summarized by obtain that the cancer risk assessment is lifetime cancer risk, therefore it is possible that the exposure characteristics of THMs may change.

USEPA recommends that risk assessment should be performed for the worst case. Therefore, this research assessed cancer risk from the highest concentration of contaminants, which was the worst situation, and additionally assessed from the average concentration as the general situation. This method assessed risk from the toxicity of each compound and then combined all risks. Actually, the compounds might have either synergistic or antagonistic effects on one another. Cancer risk assessment in this research was summarized from THMs only. But in the real situation, tap water and swimming pool water consist of many carcinogens, especially other chlorination by-products causing cancer such as haloacetic acids, haloketones and chlorophenols. Therefore, the total cancer risk should be higher than the values estimated in this paper due to the exposure to other carcinogens. 
The prevention and management of this case in the industry especially in hotel business is important from both the human and business perspectives. There is certainly a lot of room for new research in these areas to promote better industry conformity and extending its application elsewhere.

$\begin{array}{ll}\text { Nomenclatures: } \\ \% & \text { Percentage } \\ \mathrm{cm} & \text { Centimeter } \\ \mathrm{cm} / \mathrm{h} & \text { Centimeter per hour } \\ \mathrm{cm}^{2} & \text { Centimeter per square } \\ \mathrm{cm}^{3} & \text { Centimeter per cube } \\ \mathrm{d} & \text { Day } \\ \mathrm{h} / \mathrm{d} & \text { hour per day } \\ \mathrm{kg} & \text { Kilogram } \\ \mathrm{L} / \mathrm{d} & \text { Liter per day } \\ \mathrm{m} / \mathrm{h} & \text { Meter cube per hour } \\ \mathrm{min} & \text { Minute } \\ { }^{\circ} \mathrm{C} & \text { Celcius } \\ \mathrm{ug} / \mathrm{L} & \text { Microgram per liter }\end{array}$

\section{REFERENCES}

[1] Vorosmarty C. J, McIntyre P. B., Gessner M.O., Dudgeon D., Prusevich A., "Global threats to human water security and river biodiversity." Retrieved from http://epubs.scu.edu.au/cgi/viewcontent.cgi?article=2066\&context=esm_pubs. 2010.

[2] Prapat P., Benchamaporn S., Tanisa W., Sathaporn P., "Cancer Risk Assessment from Trihalomethans in Commuity Water Supply at Northeastern Thailand", International Journal of Environmental Science and Development. Vol. 4, No. 5. Retrieved from http://www.ijesd.org/papers/410-L00032.pdf. 2013.

[3] Centre for Disease Control and Prevention. "Waterborne Illness", Retrieved from https://www.cdc.gov/nceh/vsp/training/videos/transcripts/water.pdf. n.d.

[4] Health Canada. "Guidelines for Canadian Drinking Water Quality: Chlorine Guideline Technical Document', Retrieved from www.hc-sc.gc.ca/ewh-semt/pubs/water-eau/chlorine-chlore/indexeng.php. 2009.

[5] Roberta D., Rehan S., Manuel J. R., Sabrina S., Robert T., "Trihalomethane exposure in indoor swimming pool: A level III fugacity model." Water Research 45(2011) 5048-5098. Retrieved from http://www.sciencedirect.com/science/article/pii/S0043135411003903. 2010.

[6] Amir M., Mohammad M., Afshin E., Hassan K., Sepideh N., "Monitoring of THMs Concentration in Isfahan Water Distribution System and Zoning by GIS, a case study in the Center of Iran", Iranian Journal of Health, Safety \& Environment Vol. 3 No. 1, pp 421-427. Retrieved from http://oaji.net/articles/2016/509-1453517992.pdf. 2015.

[7] World Health Organization (WHO), "Disinfectant and disinfectant by-product", Environmental Health Criteria 216, Geneva. 2000a.

[8] World Health Organization (WHO), "Swimming pools, spas and similar recreational water environment", Guidelines for Safe Recreational-water Environments. Vol 2. 2000b.

[9] Lee S. C., Guo H., Lam S. M. J., Lau S. L. A., "Multipath way risk assessment on disinfection byproducts of drinking water in Hong Kong”, Environ Research. 94: 47-56. 2004.

[10] Wang G., Deng Y., Lin T., "Cancer risk assessment from trihalomethanes in drinking water" Science of the Total Environment. 387: 86-95. 2007.

[11] Panyakapo M., Soontornchai S., Paopuree P., "Cancer risk from exposure to trihalomethanes in tap water and swimming pool water", Journal of Environmental Science. Vol. 20, pp. 372-3. Retrieved from http://www.ijesd.org/papers/410-L00032.pdf. 2008.

[12] Nieuwenhuijsen M. J., "Swimming pool chlorine risk to pregnant woman", Retrieved frm http://www.imperial.ac.uk/P3296.htm. 2002. 
INTERNATIONAL JOURNAL OF ENGINEERING TECHNOLOGY AND SCIENCES (IJETS) Vol.6 (1) Dec 2016 DOI: http://dx.doi.org/10.15282/ijets.6.2016.1.2.1052

[13] America Public Health Association (APHA), "Standard methods for the examination of water and wastewater", Washington DC, US: American Public Health Association. n.d

[14] United State Environmental Protection Agency (USEPA), "Drinking water priority rulemaking: microbial and disinfection byproduct rule", 815/F/98/0014. USEPA: Environmental Protection Agency Office of Ground Water and Drinking Water. n.d

[15] United State Environmental Protection Agency (USEPA), "Guideline for cancer risk information, risk assessment", Washington DC, US: Environmental Protection Agency. n.d

[16] J. Milot, M.J. Rodriguez and J.B. Serodes, J.Environ. Manag., $60,155-171.2000$

[17] Nikolaou AD, Golfinopoulo SK, Lekkas TD, Arhonditsis GB. Factors affecting the formation of organic by-products during water chlorination: a bench-scale study. Water Air and Soil Poll 159:357-37.2004 